\title{
Reconstructing the past in a post-Ottoman village: Turkishness in a transnational context
}

\author{
Anna Zadrożna* \\ Department of Anthropology, Yeditepe University, Istanbul, Turkey \\ (Received 16 February 2016; accepted 20 June 2016)
}

\begin{abstract}
This study analyzes transformations of historiography and identity discourses by focusing on the Memory House of Ali Riza Efendi (the father of Mustafa Kemal Atatürk) as a "site of historical consciousness" which was reconstructed in the western part of the Republic of Macedonia. The House, referred to by the villagers as the "Memory House of Atatürk," was opened in 2014 in a Muslim village, Kocacık, with the support of the Turkish state. Through material and textual representations of Atatürk's life, the House speaks to the Turkishness and Turkish presence in the Balkans. The Turkishness, however, is imagined through the neo-Ottoman and Islamic prisms. The House thus becomes the locus of alternative interpretations of the past, and, consequently, narratives of Muslims' identity and origin in the region. Moreover, as it is reconstructed at the nexus of the local and the transnational, the House is also called a symbol of the "politics of brotherhood" between Macedonia and Turkey. In this way, the institution embodies the reconstruction of the past not only at the local and national levels, but also at the international level.
\end{abstract}

Keywords: historical consciousness; identity; Turkishness; Balkan Muslims; museums

\section{Introduction}

In May 2014, the "Memory House of Ali Riza Efendi," the father of Mustafa Kemal Atatür, the founder of the Turkish Republic, was opened in the mountain village of Kocacık, ${ }^{1}$ located in the municipality of Centar Župa in the western part of the Republic of Macedonia. The House was funded by the Turkish Cooperation and Coordination Agency, TİKA, to "continue traditionally good cooperation" between Macedonia and Turkey, as it was said by the Macedonian president during the opening. Located on one of the highest hills in the mountain village, the House dominates the space composed of meadows, pastures, and thinly scattered houses. In this sparsely populated region, where most houses have been abandoned due to emigration, the presence of the "Memory House" brings up many questions. For whom and why was it built, and what narrative does it represent?

Today, the majority of the inhabitants of Centar Župa, which is divided into Lower (Dolna) and Upper (Gorna) Župa, declare themselves to be Turks, whose mother tongue is Turkish. ${ }^{2}$ The literature concerning Župa describes the villages in the Upper Župa, where Kocacık belongs, as "Turkish," whereas the Lower Župa is referred to as inhabited by Torbeši or Islamicized Macedonians (Kalafat 1994; Kartal 2002; Rusić 1959).

\footnotetext{
*Email: an.zadrozna@gmail.com
} 
Accordingly, in everyday conversations the villagers draw a symbolic boundary (Barth [1969] 1998) between the Lower and the Upper Župa, describing the latter as "really Turkish:" its inhabitants have different traditions and folk costumes, and they "speak Turkish at home." In turn, identifications in the Lower Župa are more complex. Although the primary language of the majority of the villagers is Macedonian, only one village is acknowledged as "Macedonian Muslim" and of "ethnic Macedonian origin." Inhabitants of other villages declare themselves to be Turks, although their Turkishness is regularly being contested, and they are commonly called "Torbeši."

Within the literature, Muslims whose primary language is Macedonian have been named Torbeši (Dikici 2008; Risteski 2009), "Macedonians Muslims,"3 "Islamicized Macedonians" (Limanoski 1989), Macedonian-speaking Muslims (Bielenin-Lenczowska 2008), Našinci (Svetieva 2004), and "Turks who have forgotten their language." Moreover, everyday identifications of Muslims do not fit any of these categories exclusively, being contextual and relational. One can call himself/herself or a family member a Turk, a Macedonian, an Albanian, a Torbeš, or simply a Muslim (Bielenin-Lenczowska 2008; Poulton 1997; Zadrożna Unpublished manuscript), depending on the context or intention. Turkishness can be associated with Muslimness or the Ottoman legacy; Macedonianness can indicate Christianity or citizenship; and the ethnonym "Torbeš" can signify the ethnic group of Muslims whose mother tongue is Macedonian, or refer to Muslims of ethnically mixed background (Zadrożna 2013).

Such diversity of ethnonyms reflects the complex character of ethno-national categories, different political approaches of subsequent nation-states, ${ }^{4}$ and consequent politicization of Muslims and of the term "Torbeš." In the 1990s, when Macedonian nationalism was developing alongside ethno-religious lines, the state aimed to assimilate Muslims and incorporate them into the emerging nation-state by developing a narrative on the Macedonian-ethnic origin of Muslims and their forced conversion to Islam. To strengthen the representation of Macedonianness in population censuses, broad propaganda, which included derogatory narratives on Islamicization, and the implementation of anti-Turkish and antiAlbanian policies (Dimova 2007, 2013), has spread throughout the country. This required the challenging of a long-lasting religious categorization, and replacing it with national belonging, which involved the rewriting of the past.

The ways in which past events and figures are evaluated, commemorated, or presented whether in a written or material form - are intertwined with the ways they are remembered. Though belief in a common past is one of the prerequisites for the creation of commonness and groupness, including the ethnic or the national "we" (Anderson 1991; Elbasani and Roy 2015; Gellner and Smith 1996; Todorova 2004), politicization of the past is one of the means by which national ideologies operate to form the nation-state and to create a desirable present and future (Elbasani 2015; Kaneff 2004; Karakasidou 1997; Sutton 1998). In the creation of a national history, particular events from the past are being recalled, remembered, and performed, whereas others remain silenced and forgotten (Trouillot 1995).

Desirable narratives of the past are presented and commemorated in a naturalized, ritualized way within what I call "sites of historical consciousness," such as a museum, commemorations, and monuments. Through their bodily engagement with these places and spaces, ${ }^{5}$ people internalize specific narratives of the past, which shape further memories, that are collective (Assmann 1995, 2008; Connerton 1989) or public (Özyürek 2007). Memory and history are, therefore, not opposite and exclusive as Nora (1989, 8-9) argued, but meet and intertwine in what some scholars refer to as historical consciousness (Crane 2000; Stewart 2013; Sutton 1998), and through the sites of historical consciousness the past is remembered and reconstructed. 
Although elsewhere throughout Macedonia Macedonian-speaking Muslims declare themselves as Albanians, Macedonians, or Torbeši, the Lower Župa is "becoming" Turkish, and the past is being rewritten to speak for the Turkishness and for the Turkish origin of Muslims. In this article, I explore the contemporary reconstruction of the past, and consequently, identity, in this post-Ottoman, post-socialist context where different discourses, historiographies, and political powers still intertwine and compete.

\section{Identity transformations in western Macedonian villages}

In Byzantine times, Kocacik was an important Christian city protected by a fortress, the ruins of which are still preserved today. There are hypotheses that Kocacik had been Sveti Grad, and took its current name after a big war, possibly the one between the armies of Skanderbeg and Sultan Murat II in $1448^{6}$ (Rusić 1959; Stojanovski 1989). After the Ottoman conquest, Kocacik was settled by Ottoman soldiers and nomads (Yörük). The local church was converted to a mosque, and Kocacık, as part of the sancak (district) Debra-i Bala, became a center that connected the southeast with Albania and the Adriatic Sea (Stojanovski 1989).

In the course of time, resettlements of the Turks to nearby villages, intermarriages, and social interactions contributed to Turkification of the area and religious conversion. Notwithstanding remaining cultural and linguistic differences between the villages, all Muslims belonged to the same millet (religious community), and ethno-national categories as we understand them today did not exist in everyday life (Zhelyazkova 2002). The symbolic date of the nationalist turn is the Balkan Wars of 1912-1913, after which subsequent governments undertook different approaches and policies toward the participation of Muslims in the creation of the nation-states and consequent identity transformation. The Kingdom of Yugoslavia recognized Muslims, Turks, and Albanians as separate national minority categories, and in socialist Yugoslavia, "Muslims" changed to "Macedonian Muslims." Although Muslims in Tito's Yugoslavia enjoyed greater freedom than in Communist Bulgaria, nationalist policies and consequent economic hardships resulted in the mass emigration of Muslims. Until the late 1950s, the majority of the villagers emigrated, mainly to Turkey, Italy, and Germany (Zadrożna Unpublished manuscript). Kocacik became one of the remaining inhabited villages, although it is estimated that up to $90 \%$ of the people born there were living abroad.

After proclaiming independence in 1991, the Macedonian state implemented nationalist politics which aimed to assimilate Macedonian Muslims into a broader category of "Macedonians." One of the activities of Macedonian nationalists was the establishment of the "Republican Association for Cultural-Scientific Manifestations of Macedonian Muslims," led by historian Nijazi Limanoski, who aimed to mobilize Muslims on political and ideological levels. Through panels, conferences, and publications, they spoke about the centuries of the Ottoman yoke, and forced Islamicization and Turkification of "ethnic Macedonians." Conversion was also depicted as shameful betrayal, which is echoed in the most popular explanation of the name Torbeš as "one who sold own faith for a bag (Macedonian: torba) of goods." Because of that, the majority of Muslims reject the name "Torbeši" as derogatory, and prefer to be seen as Macedonians, Albanians, or Turks. Association leaders accused Turkish (and Albanian) political parties - mainly the Turkish Democratic Party (TDP), which was also effective in Lower Župa - of an anti-Macedonian agenda and the continuation of the "Turkish enslavement of the Macedonian nation" through ideological propaganda (Limanoski 1984). 
Consequently, the government banned education in Turkish in all regions of Macedonian-speaking populations, to "prevent Turkification" (Limanoski 1984). This, however, was met with resistance by Muslims who did not support the Association and wanted to learn Turkish and continue their education in Turkish. As one of my informants from Upper Župa, a man in his 40s, recalled:

In the 1990s our municipality was divided. The government established a natural border: everything up there, above the river, was to be Turkish, and everything beneath to be Macedonian. It meant that some villages located high in the mountains, including Kocacik, were left as Turkish, and all the other villages were to be Macedonian. (...) They banned education in Turkish in all the villages below the river, and all the children were supposed to be taught in Macedonian. But people started a strike (...). 47 days, almost two months, they stayed hungry at school, 47 days, why? To achieve the right for education in Turkish.

The protests failed, even though one person from Lower Župa applied to the European Court of Human rights. The case revolved around rights to education in the mother tongue, which raised the question of which language is the mother tongue of Muslims in this region, ${ }^{7}$ and of the relationship between language and ethnicity.

Although many Muslims in Macedonia (and other Balkan states) are at least bilingual and come from ethnically mixed families (Zadrożna 2015), identity debates revolve around primordialist arguments. Formal identity declarations have a crucial meaning for political recognition and reception of cultural rights, which are transmitted according to a group percentage, but only among the "national minorities" listed in the Constitutional Amendment ${ }^{8}$ (Skarić 2004). Identity has become a highly politicized issue, and narratives of belonging are also constructed on mutual contestations. Although religious conversion and cultural syncretism are seen as a natural consequence of Ottoman rule (Zhelyazkova 2002), contemporary identity disputes in Macedonia relating to Islamicization and Turkification are also sensitive issues, and ethno-nationalist narratives develop around the concept of "ethnic purity." Muslims who declare themselves Turks argue that they come from the Turks of Konya (a city in central Anatolia), and deny any possibility of having a Slavic background. "Macedonian Muslims" acknowledge past conversion, but refer to themselves as "pure" ethnic Macedonians, who speak "more real" Macedonian than people in the East or in Skopje. Torbeši, in turn, reject Macedonian origin and claim to be descendants of Bogomilian pilgrims who had voluntarily converted to Islam long before the Ottoman conquest (Dikici 2008; Zhelyazkova 2002). Those contestations are also present within the scholarship. Whereas Slavic scholars seek the "ethnic" Slav origin of Muslims, Turks prefer to see Torbešes as one of the Turkish tribes (Kalafat 1994), which was also acknowledged by some of my informants from Župa.

These competing identity discourses are in line with political views: "Macedonians" support Macedonian political parties, the majority of the "Turks" vote for the Democratic Party of Turks, and Torbeši support the Party for European Future - PEI, which actively works for the legal recognition of Torbeši as a separate ethnic group. Torbeši have also established an association called "Rumelija," which is mainly active in the neighboring municipalities of Reka and Struga, and aims to provide scientific proof that Torbeši are neither Turks nor Macedonians, but a separate ethnic group. ${ }^{9}$ Consequently, all groups challenge each other's "identity" by using arguments that challenge their "origin" by claiming that their identity declarations are of instrumental motivation or by accusing others of implementing an aggressive identity policy that aims at Albanianization, Macedonianization, or Turkification of Muslims (Bielenin-Lenczowska 2008; Risteski 2009). 


\section{The Memory House}

Work on the reconstruction of the Memory House of Ali Riza Efendi began in 1999, when a group of scientists (archaeologists, historians, and ethnologists) began research in Kocacik to "find the traces of the original house of Ali Riza Efendi, and to collect data about the history and folklore of the region," as was explained to me during my fieldwork. The official protocol of acceptance of the "house reconstruction project," as it was named, was signed in $2012^{10}$ between the representatives of TIKA, the Macedonian Ministry of Culture, and the head of the Centar Župa municipality. The museum was finally opened to the public in May 2014, with the opening ceremony appearing in the news in Macedonia and in Turkey, and was widely discussed among villagers in Lower and Upper Župa.

The opening of the Memory House had long been planned for 19 May, the Commemoration of Atatürk, Youth, and Sports Day, ${ }^{11}$ which is a Turkish national holiday. Yet, the final decision was suspended until the very last moment, on account of the accident in Soma, Turkey, on 13 May, which killed 301 coal miners. The Turkish prime minister's visit was cancelled, as well as the artistic part of the opening prepared by a local Turkish folk group. I arrived in the village a day before the opening by a night bus from Istanbul. The opening was not only a local but also an international political event, attended by the Turkish Deputy Prime Minister Emrullah Işler, President of the Republic of Macedonia Gjorge Ivanov, and Macedonian Minister of Culture Elizabeta Kančeska-Milevska. In addition, a flat LCD panel displayed a live broadcast from Ankara, where the inauguration ceremony of five TIKA projects took place in the presence of the Turkish prime minister (Figure 1).

Buses from neighboring villages and cities brought groups of schoolchildren and teachers, who then transferred to smaller local minibuses, capable of navigating the narrow and winding mountain roads. The drivers would drop their passengers off at the square

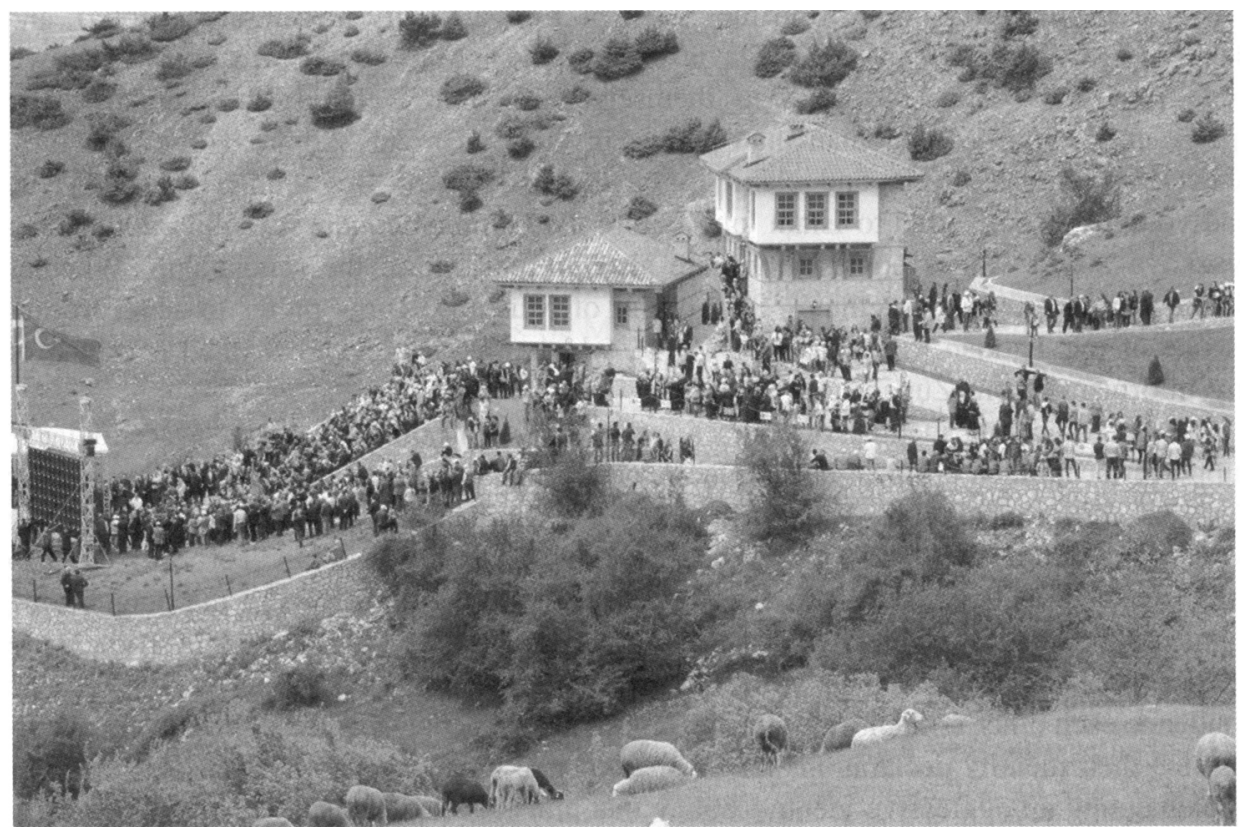

Figure 1. Opening of the Memory House. Photograph by author. 
in Kocacık, and the people would walk the last few hundred meters up the mountain road leading to the House. Children and youth equipped with Turkish flags, village women dressed in the local folk costumes, local inhabitants, and visitors composed a colorful crowd.

When after a long walk my friend and I finally arrived at the small auditorium, the Turkish prime minister's speech sounded from the speakers. His silhouette was visible on the screen over the crowd, which gathered in front of the small wooden stage. I soon realized that not everyone understood Turkish: a great number of the villagers from Lower Župa did not speak Turkish at all. ${ }^{12}$ Most people were concentrating on the immediate present; local teachers and politicians were conferring about final preparations, greeting the Macedonian president or other guests. A group of youths were dressed in T-shirts with the TİKA logo and holding banners demonstrating sympathy for Soma and support for the Turkish prime minister. Researchers and architects enthusiastically commented on the House. Villagers and youths were chatting about everyday issues, exchanging comments, thoughts, and smiles. Everybody was waiting for the signal from Ankara, which finally came at around 12:30 p.m.

The entire complex (Figure 1) as it stands today spans over 20,000 square meters and consists of the Memory House and the Family House of Kemal Atatürk's extended family. The first one possesses a memorial-exhibition segment called "Kocacik's Room,"13 which displays the permanent exhibition of items collected from the surrounding villages, as well as "Mustafa Kemal's Memory Room," 14 with the wax figure of young Atatürk dressed in a military uniform standing in the middle of the room, next to sheepskin rugs and the traditional fireplace. The latter has two floors, with rooms that step-by-step display Atatürk's family life and house a collection of wax figures of his family members. In one of the rooms Atatürk's mother, Zübeyde Hanım, dressed in a folk costume from Upper Župa, stands face to face with his father Ali Riza Efendi, who sits next to the window. A small, round,

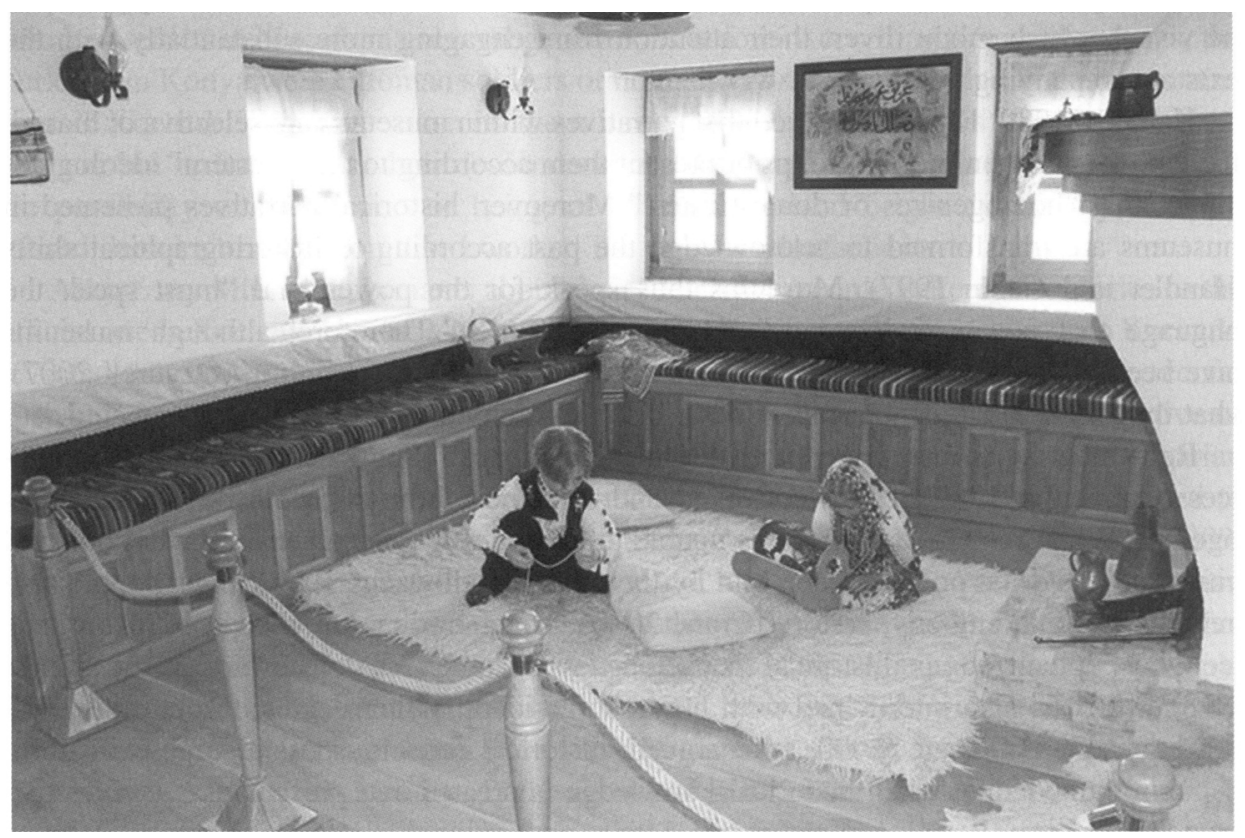

Figure 2. Atatürk and his sister Makbule. Photograph by www.tika.gov.tr. 
wooden table, colorful woollen rug, and oil lamps create the atmosphere of a modest but warm family life. In a second room (Figure 2), a young Mustafa is nestled on a woollen rug, playing next to his sister Makbule. With their blond hair and fair skin, daylight gently shining through the windows, wooden toys, and an item of clothing strewn on the sofa, the children are depicted on one of their relaxed days. The third room located on the second floor shows an old man with a thick dark blonde beard, dressed in black and white wool coat, his head in a woollen kjulah, ${ }^{15}$ solemnly bent over a book; it is Kizll Hafiz Ahmet Efendi, grandfather of Atatürk. Finally, there is an effigy of Ayşe Hanım, Atatürk's grandmother, standing in the middle of the room, focused on hand-spinning white wool.

Information panels fixed on the walls all around the museum and a booklet prepared by TÍKA in Macedonian, Turkish, and English offer brief information about the region and about Atatürk and his family's life and genealogy. Atatürk's grandfather was one of the most powerful people in Kocacik. According to oral narratives, he moved to Thessaloniki, but never broke his ties with the village. His wife Ayşe, a calm and religious woman, died before her son got married. Ali Riza Efendi, who worked as a clerk and merchandiser, died in 1887, when Mustafa was nearly seven years old. His wife Zübeyde came from a wealthy family of Konyar nomads. Just like the other women in her family, she was educated; however, she dedicated her life to the household and children. ${ }^{16}$

The panels also provide information on the village and the region: inhabitants of Kocacik are descendants of Turks from Konya, who had settled in the Balkans in the fifteenth century. The narrative on a common descent is embodied in wax figures of Atatürk and his family members: dressed in local costumes and surrounded by traditional folk objects, they resemble the people from Kocacik. As Amy Tyson (2008, 247-248) noted, museums belong to the "leisure and hospitality industry," and their aim is (among other purposes) to provide total sensory experiences and entertainment. As I observed while visiting the Memory House, many visitors do not pay close attention to what is written, especially if descriptions are numerous and too extensive. Instead, they focus on the visual, which might divert their attention from engaging more substantially with the texts accompanying the images.

Handler (1989, 18-19) observed that narratives within museums are selective or biased: they either exclude minority groups or present them according to the "western" ideology of culture that "homogenizes or domesticates." Moreover, historical narratives presented in museums are transformed to acknowledge the past according to historiographical shifts (Handler and Gable 1997). Museums thus speak for the power, and "must speak the language that power understands" (Handler 1989, 18). Therefore, although museums have been conceptualized as sites of memory (Nora 1989) or forgetting (Özyürek 2007), what they materialize is not memory, but historiography, which is to be remembered.

Remembering is intertwined with sensory experiences (Sutton 2001) and bodily practices (Connerton 1989), being conveyed and sustained through recollection and bodies together. When remembering, one is unable to distinguish clearly between what one had witnessed and what one had been told by the others (Halbwachs 1992); thus, people also "remember," and embody, history (Crane 2000). This common knowledge of history has been conceptualized as historical consciousness (Crane 2000; Stewart 2013; Sutton 1998), which is also intertwined with how people identify themselves, through the past, in the present. As Crane $(2000,144)$ argued, historical consciousness emerges as a form of public knowledge, when historical knowledge is created and presented as a collective memory. Constantly being transformed across generations, collective memory is not a set of remembering, but a process, intimately tied with the construction and negotiation 
of "identity" or "identification" (Rigney and De Cesari 2014). Drawing on that, I propose to see museums as "sites of historical consciousness," that is, places and spaces where historical narratives are materialized and textualized in selective, naturalized ways - such as they are in the Memory House - so they can be remembered and embodied.

The Memory House is a space where the past is highly politicized, but presented in a very appealing, naturalized way. Promoted as a reconstruction, it suggests natural continutity, even though the exact location of the original house has never been confirmed. ${ }^{17}$ Objects and descriptions related to Atatürk's biography intimately blend with those displaying local legacy and traditions, and they speak for kinship and common Turkish origin. Despite its official name, the House is commonly referred to as "The Memory House of Atatürk," 18 and those villagers who were not familiar with historical narratives apparently thought that Atatürk was himself born in Kocacık. One of my informants, after having read in the booklet, produced by the TIKA, that Ataturk was born in Thessaloniki, shared his concern by saying that certainly there must be something "going on" as walking through the exhibition space one could have the impression that the Turkish leader was actually born and grew up in the village.

\section{Who owns Atatürk?}

I don't believe that you can find anyone who really remembers where our ancestors came from. But I know where they came from. I have this family tree, the tree that displays the origin of Atatürk, you know, what was his origin from father's side, from mother's side. The Turks who live here are from Konya. They had come here from there, most probably with the army, as soldiers. ${ }^{19}$

Inhabitants of Kocacık, or other Muslims who consider themselves Turks, recall Atatürk's biography to confirm their Turkish origin. Like in the citation above, they believe in Atatürk's descent from Konya, which blends with and confirms the vernacular belief that contemporary Muslims who live in western Macedonia are descendants of Turks from Konya who had settled in Macedonia several generations before. According to my informants, the Turks from Konya were Ottoman soldiers or nomads (Yörük), who settled in the mountains around Kocacik. Whereas some of them came with families, others "Turkified" local women; but in both cases, their descendants are the "pure Turks." Every question about the possibility of conversion or being of ethnically mixed origin during my research caused denial and suspicion that I worked for the Macedonian state.

Asking my Muslim informants about their identity, I recorded alternative stories to the official one in Kocacik. Hatice, a woman in her 30s, whose grandfather came from Kocac1k, revealed that he would say that Ali Riza Efendi was Atatürk's stepfather and the second husband of Zübeyde Hanım. Another interesting account ${ }^{20}$ came from a representative of the Torbešian organization. Talking about Atatürk, he recalled studies by the Bulgarian researcher Veselka Tončeva, who claimed that Atatürk's father had actually migrated to Greece from the Bulgarian region of Golo Brdo, ${ }^{21}$ not from Kocacik (Tončeva 2009, 116, 291). That would suggest that Atatürk was not a "Turk from Konya," but a Bulgarian Muslim, a Pomak. My informant supported that theory, with one exception: he argued that inhabitants of Golo Brdo were not Pomaks but Torbeši, as was Atatürk himself. This would also prove that Muslims from Kocacık were Torbeši, labor migrants (gurbetči), not nomads.

I found particularly interesting how my informants evaluated Atatürk's appearance in the context of their own identity. Light complexion and blue or green eyes are not rare among Muslims in the Balkans, which for the Turks from Turkey is a sign of their nonTurkish origin. For them, as well as for Torbeši or "Macedonian Muslims" in Macedonia, 
the blue eyes and light complexion of Atatürk would also speak for his (and their) nonTurkish background. For those who identify as "Turks," however, this was the proof of their Turkishness: if one resembles Atatürk, then that person must be a Turk, and Atatürk was from Konya. ${ }^{22}$

Biographers also evaluate Atatürk's appearance and "ethnic origin" differently. Lord Kinross $(1960,24)$, for instance, remarks that Atatürk's mother Zübeyde was "pale like Slavs," and lived among the Macedonian Turks. In a similar vein, Mango $(1999,48)$ states that Atatürk inherited his appearance from Balkan ancestors, but claimed that his ancestors had been Turkish nomads to strengthen Turkish ethnic nationalism. The narrative of blue-eyed and fair-haired Turkish nomads was also invented to support this claim, which cannot be confirmed by any historical evidence.

Many details surrounding Atatürk's life and heritage remain ambiguous, and biographies provide various hypotheses, some strikingly contrasting with the narrative displayed in the Memory House. According to various sources, Atatürk was of Jewish (Scholem 2007, 732), Albanian (Mango 1999, 26-27), Bulgarian (Tončeva 2009), unspecified Turkish-nomadic (Şevket 1999, 11-12), or Turkish Anatolian (Güler 2001) origin. According to Şevket, his grandfather was not Kırmızı (or Kızıl) Hafız Efendi, but Firari Ahmet Efendi, who took his nickname "kaçak" (the one who escapes) after having escaped from Thessaloniki to the Macedonian mountains due to his involvement in a love affair with a Bulgarian girl. Hafız Mehmet Efendi, later known as Kırmızı Hafız, was Ali Rıza Efendi's brother (Şevket 1999, 31-34).

The family life of Mustafa Kemal was not as harmonious and peaceful as the story embodied by the wax figures of the Memory House suggests. Gawrych, for instance, writes that Atatürk experienced a difficult childhood, which in his later life turned him into a soldier and a leader. After his businesses failed, Ali Riza took to drinking and suffered from illness for three years until he eventually died. Atatürk's mother moved to her brother's village and remarried, and young Atatürk was sent to Selanik, where he later enrolled in the Selanik Military Preparatory School, against his mother's wishes (Gawrych 2013, 3-4). Finally, Atatürk himself was widely portrayed in Turkey as a modern, secular man, surrounded by women, being youthful, playing sports, and drinking alcohol (Özyürek 2004).

Nevertheless, those aspects of Atatürk's biography and consequent ideological views are being challenged and silenced by the Memory House, where naturalized wax figures display what Atatürk has rejected: the Ottoman legacy, and speak for neo-Ottoman and Islamic values. As Tuğal (2006, 245-252) deliberately noticed, in contrast to secular education, the rituals in which Islamists are engaging the people disrupt different hierarchies and lead to the naturalization of values they promote. This naturalization is also visible in the transnational context, where the exhibition in the Memory House tells the story of the peaceful, religious, modest family of Mustafa Kemal, which contrasts with his secular, Kemalist image.

\section{Transnational politics of brotherhood}

In recent years, in the course of diplomatic exchanges between Macedonia and Turkey, Atatürk's name has been frequently mentioned in public and political discourses as a symbol of persistent and indestructible friendly ties between the two countries. It contrasts squarely with what Drakulic (2009) called the anti-Turkish (and anti-Muslim) prejudice and antiTurkish obsession, represented by Macedonian historiography, or by the recent nationalist project "Skopje 2014." The city center was redefined as "European" 23 and rebuilt in a neoclassical/baroque style, with the sculptures of Alexander the Great, Christian Saints, and 
heroes who had fought against the Ottomans, to represent what was considered as an ethnonational heritage (Dimova 2013).

The new narratives and imaginations of the past transform the Ottomans and Turks from "enemies" to "friends" 24 (Rašidagić 2013). Public pronouncements and speeches by leading Turkish political figures reveal their desire to resurrect "the Ottoman era" (Rašidagić 2013), and narratives on long-term friendship and peaceful relations, which date back to Ottoman times, successively materialize in a public space, and enter people's houses. NeoOttomanism is not only about Turkey's "soft power," 25 as argued by Taspinar (2008, 3), but it also involves the recollection of Ottoman symbols and figures, idealization of the past, and evocation of nostalgia. Moreover, neo-Ottomanism is also about the Islamic revival that is supported by the official Turkish state and unofficial institutions (Roy 2015, 243).

Associations and organizations governed by the Turkish state, such as the Yünüs Emre Cultural Center, or associations financed through the Union of Turkish NGOs in the Republic of Macedonia (MATÜSİTEB) offer Turkish lessons and courses in Ottoman Turkish art and crafts, many of them free of charge. TIKKA finances renovations of mosques, builds schools, and sponsors students' excursions to Turkey. The "Turkish Scholarships"26 program offers attractive fellowships for studies in Turkey (Zadrożna Unpublished manuscript). Finally, Turkish soap operas widely watched in the Balkans contribute to Turkey's portrait as a modern and developed country, or depict the Ottoman past in a glorious, romanticized way.

Since most people learn their first history lesson "outside of academia, through media, celebrations, site and museum visits, movies, national holidays and primary school books" (Trouillot 1995, 20-21), reconstruction of the past requires also transformation of the space. The Memory House, which tells the story of the common (Turkish) origin of Atatürk and the villagers from Kocacik, is not the only site of historical consciousness: the symbolic transformation of the space also reaches Lower Župa. During the last few years, the municipality of Župa has established cooperation with different international and Turkish institutions, which have started providing support for the municipality. ${ }^{27}$ The school in Centar Župa, in the 1990s was still called after a Yugoslav Communist activist, Moša Pijade, is now called "the Primary School of Mustafa Kemal Atatürk," where students learn in Turkish, Macedonian, and Albanian. Next to the school, there is a college "ATA" (in Turkish: father) which teaches in Turkish. Shortly before the opening of the Memory House, the schoolyard in Centar Župa was named "Bursa Square" for the funds were received from the municipality of Bursa, a city in Turkey. Pictures of Tito, still found in some houses, are being almost forgotten. On their way to school, a new generation is looking at the fountain of Mustafa Kemal Atatürk, built in front of the school.

But how do the villagers evaluate the narratives embodied within the House? As I observed during the opening, those villagers active in local schools, associations, or the municipality were accordingly engaged in the opening ceremony: they hoped that the museum would attract tourists and, therefore, empower the local economy and development. Many villagers were mainly interested in the folk costumes and the visual aspects of the House and its surroundings. Like every public event, the opening was also an opportunity to socialize, exchange gossip, and observe others. Nevertheless, many of my informants from Lower Župa neither attended the opening nor were interested in the Memory House for a variety of reasons, such as political views or a lack of interest in history and politics. Some people were skeptical about the historical narrative represented by the House and speculated that the House must have been built for some ambiguous reasons, which included alleged corruption and political purposes. As I elaborate elsewhere (Zadrożna Unpublished manuscript), Yugoslav assimilation projects, the mass expulsion 
of Muslims, economic discrimination toward Muslims, and the nationalist politics of the contemporary Macedonian state have resulted in a common distrust toward state(s) projects and politics. The older generation remembers that the past has already been rewritten before.

\section{Conclusion}

Politicizations of the past, that is, reinterpretation of the past so that it can serve political purposes, have been subjected to academic inquiry mainly on the state-national level (Kaneff 2004; Karakasidou 1997; Sutton 1998). Kaneff's $(2004,3)$ work based on ethnographic research in the "model" Bulgarian village of Talpa explores the role of the past in contemporary local-state relations, and different ways in which the past is used by the community in order to connect to the central state. As a "model village," Talpa was actively involved in the sponsorship of a state-approved version of the past, and in return enjoyed a favorable position and benefits (Kaneff 2004). In this article, I demonstrated that the past can also be reconstructed transnationally, when narratives on the past result from negotiations between local and international actors. Following prerogatives of transnational ethnography (Amelina et al. 2012; Faist 2013) and the transnational character of the field itself, it depicted the village as no longer a bounded, isolated ethnographic field, like in the study of Kaneff (2004), but as embedded in global processes and relations.

Built in cooperation between the Turkish and Macedonian governments, and funded by the Turkish agency TIKKA, the Memory House demonstrates that "sites of historical consciousness" can be created at the nexus of local and transnational powers. Through carefully designed material and textual representations, the House not only speaks for the national historiography, but also shapes (and is shaped by) international relations and hierarchies of power. The recent discourse on Turkey's and Macedonia's "friendly relations" requires new perspectives on the past, which then becomes rewritten accordingly. In this way, the House also contributes to forgetting (Özyürek 2007), by replacing the narratives of conquest, slavery, and conversion, with those of common legacy.

Referred to as "reconstruction," the House pretends authenticity and claims primordial and cultural ownership upon the space, people, and memory. Atatürk's biography is presented as naturalized truth to speak for Turkishness; to confirm the Turkish ethnicity of Atatürk, and the Turkish origins of Muslims in the Balkans; and to justify the Turkish presence in Macedonia and the Turkish state's involvement in Macedonian politics, economy, and popular culture. This opens an intriguing question of "who is a Turk," which can be approached beyond and within ethnic, national, religious, and racial categorizations. Turkishness was perceived differently from within and outside of the Ottoman Empire, and its meaning changed after the establishment of the Turkish Republic (Güvenç 2002). Whereas for Europeans "Turkishness" has been commonly associated with the East, the Orient, and with Muslimness (Sulstarova 2015), for Turkish citizens it has been for a long time a designation of secularism, in recent years being reformulated by the ongoing debate on Islamism, Kemalism, and, lately, neo-Ottomanism. Nevertheless, whereas within the Turkish state different ideologies compete and intermingle, the Turkishness displayed within the Memory House is associated with Islamic values and ethno-nationalist ideology. Being a symbol of secularism in Turkey, Atatürk of the Memory House is depicted in a way in which he can embody those values.

Although the House challenges alternative narratives on Macedonian or Torbešian identity or origin, Muslims in Macedonia are not passive consumers of political projects and narratives, but active agents involved in constructing and evaluating their past and identity. 
Turkification of the Lower Župa should not be seen only as a reaction toward discriminatory politics of the Macedonian state, but as active entrepreneurship of the local leaders who maintain relations with Turkish institutions, and as a form of self-identification of Muslims. The example of Torbeši, in turn, shows how the minority which was refused legal recognition tries to challenge discourses offered by both Macedonian and Turkish states by proposing alternative interpretations of the past. These intertwining and competing narratives of the past reflect states' national and transnational strategies and hierarchies of power, as well as peoples' strategies and desires.

Like identity, historical consciousness is not a homogeneous but rather a multilayered and complex process which can encompass apparently contradicting narratives of the past, not only within one nation-state, as shown by the project Skopje 2014 and the Memory House, but also within one community, as demonstrated by different evaluations of Muslims' "origin" in Župa. This process is being constantly negotiated by and among different powers and communities, and transformed and reconstructed across generations. In these processes, the individual becomes a social actor and an agent, a social individual (Tonkin 1995), ${ }^{28}$ who internalizes or rejects cultural propositions. I finished my research too soon after the opening of the Memory House, and it might still be too early to conclude on how the narrative presented within the House will be further "remembered" and forgotten, and how it will affect alternative narratives on the past, the present, and the future. It can be argued, however, that the Memory House represents and contributes to the Islamic, neoOttoman revival in the Balkans, and to the recent shift in the power hierarchy with a growing Turkish position within the region.

\section{Acknowledgements}

I am grateful to Arolda Elbasani, Jelena Tošić, and Galina Oustinova-Stjepanovic for inspiring theoretical remarks at different stages of this paper. I thank my colleagues at the University College London for their inspiring comments, and Katherine Meier for language editing. I am also indebted to my interlocutors and friends who told me their stories and guided me through the field.

\section{Funding}

This work was supported by the Scientific and Technological Research Council of Turkey (TÜBITAK) [2215 - PhD Fellowship Program for Foreign Citizens].

\section{Notes}

1. The village has two official names: Turkish: Kocacık, and Macedonian: Kоџаџик (transliterated as Kodžadžik). All inhabitants of Kocacık consider themselves Turks; hence I use the Turkish version.

2. According to the population census conducted in $2002,80 \%$ of the population consider themselves Turks, while 12\% consider themselves Macedonians, and 7\% Albanians (Source: Census of Population, Household and Dwellings in the Republic of Macedonia 2002).

3. This term is often wrongly translated from Macedonian as "Macedonian Muslim," which, however, does not reflect its original meaning: "Makedonci Muslimani" - which was used in Macedonian literature and legislation - literally means "Macedonians Muslims" - "Makedonci" is a noun in a plural form, not an adjective (which is "Makedonski").

4. After the Balkan Wars, western Macedonia subsequently belonged to the Kingdom of Serbia and Yugoslavia, Socialist Yugoslavia, and the Republic of Macedonia established in 1991.

5. I differentiate between place and space, understanding the latter as broader than the placed location (Gupta and Ferguson 1992), including, for example, the Internet. 
6. Another explanation is that the name is derived from an important male figure (Tr.; koca) (Rusić 1959).

7. The online source is http://echr.ketse.com/doc/62059.00-en-20011122/view/.

8. The state is obliged to finance education in languages spoken by at least $20 \%$ of the municipality's population, and recognized minorities have a guaranteed right for representation in parliament with the relevant number of job positions in the public sector.

9. The movement, however, does not have the support of all "Torbeši;" thus, it shall not be seen as an "ethnic group" itself.

10. See http://www.TiKA.gov.tr/yazdir.php?haber=240.

11. It is the commemoration of the beginning of the Turkish War of Independence, which started in 1919.

12. I talked with my interlocutors in Macedonian or Turkish.

13. The translations are Tr.: Kocacık Odası, Mac.: Коџаџик Соба.

14. The translations are Tr.: Mustafa Kemal Anı Odası, Мас.: Спомен Соба на Мустафа Кемал.

15. The original is ќулах, a traditional hand-made head cover for men made of white or/and black wool.

16. Selected from TIKA's booklet about the museum, entitled "The Memory House of Ali Riza Efendi, Father of Mustafa Kemal Atatürk" and translated by the author. In the original, the title is "Mustafa Kemal Atatürk ün Babsı Ali Rıza Efendi Anı Evi" TíKA.

17. I was told that the original house was most probably located down the hill, in the village.

18. In Macedonian: Спомен Куќа на Ататурк

19. From an interview with a 40-year-old male, August 2012.

20. Both interviews took place in 2012.

21. I use the Macedonian name of the region, which in Bulgarian is "Golo Bărdo."

22. Some of my informants would joke that as a blue-eyed blonde, I also looked Turkish (they knew that I was Polish) and that I resembled the Turks from the Black Sea region, known for their light complexion.

23. "Europe" was defined in opposition to the Ottoman, to Islam, and to the "barbarian 'East"” (Sulstarova 2015; Zadrożna 2015).

24. The process of history rewriting had started during the debate around Macedonian independence in the 1990s, when the more realistic threat to the newly established state were Greek and Bulgarian nationalist policies, which questioned the Macedonian right to independence, the use of national symbols, or even the existence of the Macedonian nation (Danforth 1993). In turn, the Turkish state recognizes the Republic of Macedonia under its name.

25. Consequently, some actors such as Serbia and Albania accuse Turkey of pursuing a "neoOttoman agenda" (Petrović and Reljić 2011, 169).

26. See http://www.turkiyeburslari.gov.tr/.

27. This intensified especially after 2012 , when the municipality elected as leader a young politician from the TDP, Arijan Ibraim, who was a graduate of a university in Turkey.

28. Tonkin (1995, 101-103) uses the term "social individual," recognizing the individual as a social actor affected by and affecting others, who experiences more or less effective socialization and education.

\section{References}

Amelina, Anna, Devrimsel D. Nergiz, Thomast Faist, and Nina Glick Schiller, eds. 2012. Beyond Methodological Nationalism: Research Methodologies for Cross-Border Studies. New York: Routledge.

Anderson, Benedict. 1991. Imagined Communities: Reflections on the Origin and Spread of Nationalism. London: Verso.

Assmann, Jan. 1995. "Collective Memory and Cultural Identity." New German Critique 65: 125-133.

Assmann, Jan. 2008. "Communicative and Cultural Memory." In Cultural Memory Studies: An International and Interdisciplinary Handbook, edited by A. Erll and A. Nünning, 109-118. Berlin: Walter de Gruyter.

Barth, Fredrik. [1969] 1998. "Ethnic Groups and Boundaries." In Ethnic Groups and Boundaries. The Social Organization of Culture Difference, edited by Fredrik Barth, 9-26. Long Grove, IL: Waveland Press. 
Bielenin-Lenczowska, Karolina. 2008. "The Construction of Identity in a Multi-ethnic Community: A Case Study on the Torbeši of Centar Župa Commune, Western Macedonia (FYROM)." Ethnologia Balkanica 12: 167-181.

Census of Population, Household and Dwellings in the Republic of Macedonia. 2002. Book XIII: Total Population, Household and Dwellings According to the Territorial Organization of the Republic of Macedonia, 2004. Skopje, Maj 2005. Accessed June 3, 2014. http://www. stat.gov.mk/Publikacii/knigaXIII.pdf

Connerton, Paul. 1989. How Societies Remember. Cambridge: Cambridge University Press.

Crane, Susan A. 2000. Collecting and Historical Consciousness in Early Nineteenth-century Germany. Ithaca, NY: Cornell University Press.

Danforth, Loring. 1993. "Claims to Macedonian Identity - The Macedonian Question and the Breakup of Yugoslavia." Anthropology Today 9 (4): 3-10.

Dikici, Ali. 2008. "The Torbešes of Macedonia: Religious and National Identity Questions of Macedonian Speaking Muslims." Journal of Muslim Minority Affairs 28 (1): 27-43.

Dimova, Rozita. 2007. "From Past Necessity to Contemporary Friction: Migration, Class and Ethnicity in Macedonia." Max Planck Institute for Social Anthropology, Working Paper No. 4, Halle/Salle, 1-14.

Dimova, Rozita. 2013. Ethno-Baroque: Materiality, Aesthetics and Conflict in Modern-day Macedonia. New York: Berghahn Books.

Drakulic, Slobodan. 2009. “Anti-Turkish Obsession and the Exodus of Balkan Muslims.” Patterns of Prejudice 43 (3-4): 233-249.

Elbasani, Arolda. 2015. "Introduction: Nation, State and Faith in the Post-Communist Era." In The Revival of Islam in the Balkans: From Identity to Religiosity, edited by Arolda Elbasani and Olivier Roy, 1-23. Basingstoke: Palgrave Macmillan.

Elbasani, Arolda, and Oliver Roy, eds. 2015. The Revival of Islam in the Balkans: From Identity to Religiosity. Basingstoke: Palgrave Macmillan.

Faist, Thomas. 2013. "The Mobility Turn: A New Paradigm for the Social Sciences?" Ethnic and Racial Studies 36 (11): 1637-1646.

Gawrych, George W. 2013. The Young Atatürk: From Ottoman Soldier to Statesman of Turkey. London: I.B. Tauris.

Gellner, Ernst, and Anthony D. Smith. 1996. "The Nation: Real or Imagined? The Warwick Debates on Nationalism." Nations and Nationalism 2 (3): 357-370.

Güler, Ali. 2001. Karaman`dan Kocacık’a Kızıl Oğuzlar Atatürk ün Soyu. Ankara: GÖK.

Gupta, Akhil, and Ferguson James. 1992. "Beyond Culture: Space, Identity and the Politics of Difference." Cultural Anthropology 7 (1): 6-23.

Güvenç, Bozkurt. 2002. The Other. Turks' Quest for Identity \& Image. Istanbul: Alkım.

Halbwachs, Maurice. 1992. "The Reconstrucion of the Past." In On Collective Memory, edited by L. A. Coser, 37-51. Chicago, IL: University of Chicago Press.

Handler, Richard. 1989. "Ethnicity in the Museum." In Negotiating Ethnicity, edited by Susan Keefe, 18-26. Bulletin no. 8. Washington, DC: National Association for the Practice of Anthropology.

Handler, Richard, and Eric Gable. 1997. The New History in an Old Museum: Creating the Past at Colonial Williamsburg. Durham, NC: Duke University Press.

Kalafat, Yaşar. 1994. Makedonya Türkleri (Türkmenler, Torbeşler/Türkbaş, Çenkeriler ve Yörükler) Arasinda Yaşayan Halk Inançları [Macedonian Turks (Turkmens, Torbeshes/Turkbash, Chenkeris and Yoruks)]. Istanbul: Türk Dünyası Araştırmalar Vakfı.

Kaneff, Deema. 2004. Who Owns the Past? The Politics of Time in a "Model" Bulgarian Village. New York: Berghahn Books.

Karakasidou, Anastasia. 1997. Fields of Wheat, Hills of Blood. Passages to Nationhood in Greek Macedonia, 1870-1990. Chicago, IL: University of Chicago Press.

Kartal, Numan. 2002. Atatürk ve Kocacık Türkleri [Atatürk and the Turks of Kocacık]. Ankara: T.C. Kültür Bakanlığı.

Kinross, Lord (John Patrick Douglas Balfour). 1960. Atatürk Bir Milletin Yeniden Doğuşu [Atatürk: The Rebirth of a Nation]. Istanbul: Exisehir.

Limanoski, Nijazi. 1984. Makedonci Muslimani: Kulturno Naučni Manifestacii na Makedoncite Muslimani [Macedonians Muslims: Cultural-Scientific Manifestations of Macedonians Muslims]. Skopje: Makedonska Kniga.

Limanoski, Nijazi. 1989. Islamskata Religija i Islamiziranite Makedonci [Islamic Faith and Islamized Macedonians]. Skopje: Makedonska Kniga. 
Mango, Andrew. 1999. Atatürk. London: John Murray.

Nora, Pierre. 1989. "Between Memory and History: Les Lieux de Mémoire." Representations 26: 7-24.

Özyürek, Esra. 2004. "Miniaturizing Atatürk. Privatization of State Imagery and Ideology in Turkey." American Ethnologist 31 (3): 374-391.

Özyürek, Esra. 2007. "Introduction: The Politics of Public Memory in Turkey." In The Politics of Public Memory in Turkey, edited by E. Özyürek, 1-15. Syracuse, NY: Syracuse University Press.

Petrović, Žarko, and Dusan Reljić. 2011. "Turkish Interests and Involvement in the Western Balkans: A Score-Card." Insight Turkey 13 (3): 159-172.

Poulton, Hugh. 1997. "Changing Notions of National Identity Among Muslims in Thrace and Macedonia: Turks, Pomaks and Roma." In Muslim Identity and the Balkan State, edited by Hugh Poulton and Suha Taji-Farouki, 82-102. London: Hurst.

Rašidagić, Kenan. 2013. "A Critical Analysis of Turkish Foreign Policy towards the Western Balkans." In Turkish-Balkan Relations: The Future Prospects of Cultural, Political and Economic Transformations and Relations, edited by H. Korkut and E. Nuroglu, 179-196. Istanbul: Tasam.

Rigney, Ann, and Chiara De Cesari. 2014. Transnational Memory: Circulation, Articulation, Scales. Berlin: De Gruyter.

Risteski, Ljupčo. 2009. "Dynamika tożsamości Torbeszów w Republice Macedonii” [Dynamic of Torbeshes' Identity]." In the Republic of Macedonia]. In Sasiedztwo w Obliczu Konfliktu: Relacje spoteczne $i$ etniczne wzachodniej Macedonii - refleksje antropologiczne, edited by K. Bielenin-Lenczowska and K. Paczóska, 179-191. Warszawa: DiG.

Roy, Olivier. 2015. "Conclusions." In The Revival of Islam in the Balkans. From Identity to Religiosity, edited by Arolda Elbasani and Olivier Roy, 242-251. Basingstoke: Palgrave.

Rusić, Branislav. 1959. Župa Debarska [The Debar Župa]. Skopje: Filozofski Fakultet na Univerzitetot-Skopje.

Scholem, Gershom. 2007. "Doenmeh.” In Encyclopaedia Judaica, Vol. 5, edited by Fred Skolnik and Michael Berenbaum, 730-733. Farmington Hills, MI: Macmillan.

Skarić, Svetomir. 2004. "Ohrid Agreement and Minority Rights." In Prospects of Multiculturality in Western Balkan States, 94-110. Belgrade: Ethnicity Research Center, Friedrich Ebert Stiftung.

Stewart, Charles. 2013. Dreaming and Historical Consciousness in Island Greece. Cambridge, MA: Harvard University Press.

Stojanovski, Aleksandar. 1989. Makedonija vo Turskoto Srednovekovie (od Krajot na XVI-pocetokot na XVIII Vek) [Macedonia in Turkish Middleage (From the End of the XVIth to the beginning of XVIII Century)]. Skopje: Kultura.

Sulstarova, Enis. 2015. "Islam and Orientalism in Contemporary Albania." In The Revival of Islam in the Balkans. From Identity to Religiosity, edited by Arolda Elbasani and Olivier Roy, 23-41. Basingstoke: Palgrave.

Sutton, David. 1998. Memories Cast in Stone: The Relevance of the Past in Everyday Life. London: Routledge.

Sutton, David. 2001. Remembrance of Repasts. An Anthropology of Food and Memory. Oxford: Berg.

Svetieva, Aneta. 2004. "Politicisation of the Ethnic Identity of the Torbesh (the "Nashinci')." EthnoAnthropoZoom. Accessed June 22, 2013. http://www.iea.pmf.ukim.edu.mk/EAZ/EAZ_ 03/EAZ_2004_PDF/EAZ_2003_Ponizeni_Balkan_Ang.pdf.

Şevket, S. A. 1999. Tek Adam: Mustafa Kemal 1881-1919. Cilt I. Istanbul: Remzi Kitabevi.

Taspinar, Ömer. 2008. “Turkey's Middle East Policies. Between Neo-Ottomanism and Kemalism.” Carnegie Papers. Carnegie Endowment for International Peace 10: 1-29.

Todorova, Maria, ed. 2004. Balkan Identities: Nation and Memory. New York: New York University Press.

Tončeva, Veselka. 2009. Blgarite ot Golo Brdo, Republika Albania: Tradicii, Muzika, Identicnosti [Bulgarians from Golo Brdo, The Republic of Albania: Traditions, Music, Identities]. Rod: Sofia.

Tonkin, Elizabeth. 1995. Narrating Our Pasts: The Social Construction of Oral History. Cambridge: Cambridge University Press.

Trouillot, Michel R. 1995. Silencing the Past: Power and the Production of History. Boston, MA: Beacon Press.

Tuğal, Cihan Z. 2006. "The Appeal of Islamic Politics: Ritual and Dialogue in a Poor District of Turkey." The Sociological Quarterly 47: 247-273. 
Tyson, Amy M. 2008. "Crafting Emotional Comfort: Interpreting the Painful Past at Living History Museums in the New Economy." Museums and Society 6 (3): 246-262.

Zadrożna, Anna. 2013. "I Am Muslim but I Am the European One: Contextual Identities among Muslims from Western Macedonia in Everyday Practices and Narratives." Anthropological Journal of European Culture 2 (22): 35-52.

Zadrożna, Anna. 2015. "Love and Boundaries: Inter-faith and Inter-ethnic Relationships among Macedonian-speaking Muslims." In The Revival of Islam in the Balkans. From Identity to Religiosity, edited by Arolda Elbasani and Olivier Roy, 142-162. Basingstoke: Palgrave.

Zadrożna, Anna. Unpublished manuscript. "Turkish-ness across the Borders: Politics, Practices, Memories and Belongings. Transnational Ethnography among Macedonian-speaking Muslims."

Zhelyazkova, Antonina. 2002. "Islamization in the Balkans as Historiographical Problem: The Southeast-European Perspective." In The Ottomans and the Balkans: A Discussion of Historiography, edited by F. Adanir and S. Faroqhi, 223-266. Leiden: Brill Academic. 